\title{
Study on knowledge, attitude \& practice about rabies \& pet animals among school children in bangladesh
}

Volume 4 Issue I - 2017

\section{Introduction}

Rabies is a lyssavirus infection resulting in acute encephalitis or meningoencephalitis that is virtually always fatal. ${ }^{1}$ The disease can be caused by several different rabies and rabies-like viruses. Rabies is an infectious and contagious viral disease. It has been known since the ancient days of 2300 B.C. This lethal virus still exists in almost all parts of the world. Once infected, and left untreated, this disease is $100 \%$ fatal. ${ }^{1}$ The rabies virus is concentrated in the saliva, mucous membranes and central nervous tissue of a rabid animal. Only humans, and other mammals, can become infected through a cut or scratch from animal with rabies or if the rabies virus comes in contact with the moist tissues of the mouth, nose or eyes. ${ }^{2}$

Rabies is a neglected tropical disease that predominantly affects the most vulnerable humans-children living in the most disadvantaged areas of the poorest countries. ${ }^{1}$ Many countries have successfully reduced the impact of the disease by tackling the gap between public and animal health through a concerted "one health" approach. ${ }^{2}$ Clinicians worldwide need to be aware of rabies and vigilant about the possible exposure of patients to infection because timely prevention is life saving.

Countries predominantly affected by rabies often have poor diagnostic and reporting capacities, leading to a lack of accurate data and considerable uncertainty around estimates of global burden. ${ }^{3}$ Efforts to improve data quality have been hampered by duplicative reporting systems requirements to different agencies representing animal or human health. In 2011 the World Health Organization reporting database Rabnet closed, as limited data and under-reporting contributed to a lack of priority for this disease. ${ }^{3}$ In the absence of high quality reporting, estimates of global burden in 2010 ranged from 26400 to 61000 deaths, depending on the method applied. ${ }^{1}$ Considerable geographical variation exists worldwide, with $95 \%$ of rabies cases in humans occurring in Africa and Asia $84 \%$ of these in rural areas. ${ }^{2}$ Dogs are the source of infection in more than $99 \%$ of cases in humans. ${ }^{3}$

Those living in rabies endemic countries, without control measures in dogs and wildlife and access to post-exposure prophylaxis, are at greatest risk. Half of the human population worldwide lives in countries endemic for canine rabies. ${ }^{2}$ Children are especially at risk because they are more likely to approach animals without caution, including appear entry tame wild animals, and therefore to be attacked and bitten, especially on the arms and face. In rabies-free countries, all cases of terrestrial rabies are linked with importations rabies-like viruses in bats do not affect a country's rabies free status. Since 1946, 25 cases of human terrestrial rabies have been reported in the United Kingdom, associated with exposures to rabid dogs in countries such as the Philippines, Nigeria, India, and South Africa. ${ }^{3}$ Travelers and residents in rabies endemic countries should avoid contact with freeroaming animals, especially dogs. Vampire bats have been associated with several rabies outbreaks in South America. Bats carry rabies-

\author{
Moazzem Hossain \\ Directorate of Health Service, Bangladesh
}

Correspondence: Moazzem Hossain, Prof. of Microbiology Director (Disease Control), CDC Directorate of Health Service, Bangladesh, Email moazzem.iacib@gmail.com

Received: February 12, 2016 | Published: February 21, 2017

like viruses (rabies related lyssaviruses) even in terrestrial rabies-free countries in Europe and Australia. ${ }^{4}$

In 2002, a patient developed rabies after exposure to a bat, the only case acquired in the United Kingdom in over a century. ${ }^{5}$ In Canada, six of eight cases identified nationally since 1970 have been attributed to infections with rabies strains associated with bats. ${ }^{6}$ Although bats may be more important as reservoirs of rabies-like viruses than sources of infection in humans, people need to be aware of the risk of acquiring rabies from bats and seek immediate medical attention should they or their family members have contact.

Lyssaviruses cannot cross intact skin. Rabies gets into the body through wounds or direct exposure of mucous membranes, usually as a result of bites from infected animals, or through transplantation of tissues or organs from someone who died from rabies. Humans are an end host; anecdotal cases of transmission from human to human have not been confirmed outside of transplantation, including transmission from patients to healthcare workers. ${ }^{7}$ The incubation period is variable, with a mean incubation time in one study of 273.6 days median 80 days, range 12 days to 10 years. $^{2}$ The longer incubation periods emphasize that post-exposure prophylaxis is always indicated even if exposure occurred months or years earlier, provided neurological symptoms have not developed.

There are two ways that rabies symptoms appear, dumb and furious. Both can cause abnormal behavior. Immediately prior to death, animals with furious rabies will appear to be 'mad' frothing at the mouth and biting anything that gets in their way. They may show extreme excitement and attack stationary things or animals. Bouts of furious rabies usually alternate with periods of depression. In dumb rabies, there is no 'mad' period. With dumb rabies, paralysis, usually of the lower jaw and a drooping head are the signs of the disease. The paralysis quickly spreads to limbs and vital organs and death quickly follows. Animals with dumb rabies may become depressed and retreat to isolated places. Some may appear 'tame', having no fear of humans. In Bangladesh dog is the main transmitter of the disease. Livestock loss due to rabies is also a significant contributor to livelihood insecurity. Most of the victims ( $>80 \%)$ are children age 
6-16 yrs transmitted by dog bite mainly in $99 \%$ cases and most of the deaths occur in Asia and Africa. A recent survey by Government of Bangladesh's Disease Control Unit of Ministry of Health indicates that the number of rabies death is at least 2335 per year and more than 300,000 persons receive post-exposure treatment per year. ${ }^{8-11}$

To eliminate the health hazardous in our poor people who are not able to treat in proper time due to financial crisis, we want to study Knowledge, Attitude and Practice about rabies \& Pet animals amongst Secondary School Children in Bangladesh. Social Science Research Unit, Ministry of Planning, Government of Bangladesh financed IACIB to implement the Project. In this proposed project the teachers will be trained who will in turn teach the students to protect themselves from rabies.

\section{Rationale}

Rabies is a viral zoonotic neglected disease, which infects domestic and wild animals (dog, cat, fox, jackal, mongoose, etc). Records from Infectious Disease Hospital (IDH) in Dhaka indicates that approximately 300 to 500 animal bite cases attend to the outpatient clinic daily and 150 cases of human rabies are admitted to the IDH every year. It is likely that the number of patients admitted for rabies treatment is less than the actual demand due to an over burdened health system and inadequate treatment facilities. The exact magnitude of the problem is much greater but due to an inadequate surveillance system, the actual number is unknown. Livestock loss due to rabies is also a significant contributor to livelihood insecurity. Majority of the population cannot afford modern tissue culture vaccine (TCV) but only use the Sheep brain Nerve Tissue Vaccine (NTV) which is very neurotoxic. The World Health Organization discourages use of NTV and the Member countries phased out its use by 2006. Except Bangladesh, Myanmar and Pakistan in Asia, all countries have already discontinued the production and use of NTV. Despite being provided at a subsidized rate, supply of NTV is not sufficient. The poor and ultra-poor do not have the financial means to pay for rabies prophylaxis and/or transport to health facilities to receive treatment. The strategy plan outlines human rabies diagnosis and treatment, animal rabies vaccination, the implementation of Animal Birth Control (ABC), social mobilization and awareness about rabies and preventive measures, especially among children. As the children are mostly affected by rabies, it is therefore important to develop an understanding of testing the modern prevention and control strategy of rabies among school students through school teachers, so that students know how to behave with dogs and prevention of rabies through dog bite. In this project IEC materials will be prepared, printed and distributed. Pre and Post KAP study will be done among the students. Teachers will be oriented on prevention of rabies, who in turn will teach the students. IACIB will contribute its own existing cinema van, multimedia projector, screen for documentary film show etc. Considering the importance of this Neglected disease of innocent children the Resolution of recent Global Conference on Rabies control held in Seoul, Korea from 7-9 Sep 2011 also recommended for taking project to aware children on prevention of dog bite and accordingly this project is undertaken.

\section{Objectives}

\section{General objectives}

To know the knowledge, attitude \& practice about rabies \& pet animals among school going children in Bangladesh.

\section{Specific objectives}

i. To know the health education among school children on rabies to reduce deaths. ii. To get information about the harmful effect of dog bite and rabies control.

iii. To sensitize the students and teachers of school about rabies.

iv. To develop an understanding of testing the modern prevention and control strategy of rabies among school students through school teachers.

v. To get knowledge of the students about the nature of dog bite.

vi. To educate the behave with dogs and prevention of rabies through dog bite.

\section{Major issues addressed in the study}

\section{General objectives}

To know the knowledge, attitude \& practice about rabies \& pet animals among school going children in Bangladesh.

\section{Specific objectives}

i. To know the health education among school children on rabies to reduce deaths.

ii. To get information about the harmful effect of dog bite and rabies control.

iii. To sensitize the students and teachers of school about rabies.

iv. To develop an understanding of testing the modern prevention and control strategy of rabies among school students through school teachers.

v. To get knowledge of the students about the nature of dog bite.

vi. To educate the behave with dogs and prevention of rabies through dog bite.

\section{Methodology}

\section{Study design}

This study was designed as cross sectional descriptive type of observational study.

\section{Study period}

This present study was conducted from February to December' 2014 for a period of 11 (Eleventh) month.

\section{Selection of study areas}

A total number of 2 schools were selected by judgment sampling from Birulia and Savar Union Parishad under Savar Upozila of Dhaka district, where "Filaria and General Hospital" under IACIB is located. Although the selected study area is under Dhaka districts and adjacent area of Savar municipal corporation but rural fast growing industrial area where as various kinds of school students are studied by whose come from every part of the country with their parents or proper guardians. So that the judgment sampling must be represented the total populations which is helps us to find out the actual results.

\section{Type of information}

Both qualitative and quantitative data have been collected through field survey. All information and data were collected from primary sources by using judgment sampling techniques. A total of 2 schools have been selected by judgment \& Cluster sampling from Birulia \& Savar Union Parishad under Savar Upozila of Dhaka district, where "Filaria and General Hospital" under IACIB is located. The total 
number of students under the study are 400 (Four hundred) from class six to class ten and a total of 50 teachers were included in the study according to judgment sampling methods. The 400 (Four hundred) samples were divided into two clusters like 200 (Two hundred) for Pre-KAP survey and 200 (Two hundred) for Post-KAP survey respectively. Pre and Post KAP survey cluster were divided into five sub cluster and each sub cluster containing 40 (Forty) data. Moreover each 40 (Forty) data were divided into two school so that from each class of each school contained 20 (Twenty) respondents, who faced the interview as a primary source. The middle period of pre and post survey, the teacher workshop were held to train up the respective class teacher so that they teach their students about rabies.

Under this project IACIB has conducted the following activities:

i. Advocacy meeting with teachers on rabies control.

ii. Teaching to the students on how to behave with dogs and its prevention of rabies through dog bite.

iii. Knowledge and awareness building on rabies education and reduce from rabies deaths amongst school children aged 6-16 years in project period by $100 \%$.

iv. Pre \& Post intervention KAP survey among students

v. Literature review, Study design, Questionnaire development, Training of the data collector, Data collection, Data entry, Data visualization, Analysis, Report preparation and Result presentation.

\section{Sampling and selection of respondents}

About two schools of students were interviewed from total 400 students selected by regular random basis judgments and cluster sampling covering five classes. It was planned to interview 40 respondents from each class or cluster of students. So, the study has covered 5 categories of respondents and same set of questionnaires have been administered for the interest of study. All survey locations were selected from Union. But teachers, guardians, local formal or informal leaders, from nearby village or Schools (where household survey was conducted) have selected.

\section{Preparing study instruments and survey teams}

A draft concept paper on this study was shared with relevant persons and students by whom are working on various health issues with the government and other agencies. After finalization of the paper questionnaires were prepared for survey, which has been shared in a workshop to modify further. Based on the comments and suggestions from the workshop, all instruments were further modified. For conducting survey, one survey teams comprising of seven members each were formed. One member was responsible for coordination amongst the team. Each team has covered two Schools.

\section{Data quality}

Quality of data was ensured at both field level and processing level. Rigorous training was imparted to the field officers about collection of data and cross checking. In addition, one coordinator has coordinated the whole process. A continuous interaction was held as per need amongst the field officers and principal investigator and co-investigator (analyst) through cell phone correspondence. All data were compiled and edited meticulously. The data were screened and were checked for any missing values and discrepancy. All omissions and inconsistencies were corrected and were removed methodically.

\section{Data processing and analysis}

Computer based statistical analysis were carried out with appropriate techniques and systems. All data were recorded systematically in preformed data collection form (questionnaire) and quantitative data were expressed as mean and standard deviation and qualitative data were expressed as frequency distribution and percentage. Data was presented on a categorical scale compared between the groups using Chi-square (X2) or Fisher's Exact Probability test, while the data presented on a quantitative scale was compared between the groups using Student's ' $t$ ' test.

For all analytical tests, a probability $(\mathrm{p})$ value of $<0.05(\mathrm{p}<0.05)$ was considered statistically significant and $p<0.01$ was considered highly significant but $\mathrm{p}>0.05$ was taken as non-significant. Statistical analysis was performed by using window based computer software devised with Statistical Packages for Social Sciences (SPSS-17) (SPSS Inc, Chicago, IL, USA). 95\% confidence limit was taken. The summarized data was interpreted accordingly and was then presented in the form of tables.

\section{Household respondents' characteristics}

\section{Districts type of respondents households}

Normally all the schools of the Union can be divided into five types viz. Class VI, VII, IIX, IX \& X plain. Birulia \& Savar Union, Savar, Dhaka has had 19 High school, or School \& Colleges. To take sample proportionately, all types schools have been covered by the study area where as Filaria and General hospital have situated under IACIB.

\section{Location type of respondent households}

Hence household means type of class based on school. Both of schools are taken from Birulia and Savar Union, Savar Upazilla at Dhaka district (Table 1).

Table I Work plan with a schedule for implementation

\begin{tabular}{|c|c|c|c|c|c|c|}
\hline \multirow{2}{*}{\multicolumn{2}{|c|}{ SI NoResearch Activities }} & \multicolumn{5}{|c|}{$\begin{array}{l}\text { Activity to be done in } 5 \\
\text { Month(s) }\end{array}$} \\
\hline & & I & 2 & 3 & 4 & 5 \\
\hline \multirow{3}{*}{ | } & $\begin{array}{l}\text { Selection of } 2 \text { High Schools under the } \\
\text { project with } 1500 \text { students }\end{array}$ & $x$ & & & & \\
\hline & Recruitment of 2 data collector & $\mathrm{X}$ & & & & \\
\hline & $\begin{array}{l}\text { Training to data collector on Rabies, } \\
\text { its prevention and treatment and data }\end{array}$ & $X$ & & & & \\
\hline
\end{tabular}
collection.

Pre KAP study on Rabies, its prevention

2 and treatment among 200 students (40 students from each class)

Preparation/ development and printing of

3 awareness raising/ IEC materials (10000 $\times \times$ Leaflets )

Distribution of training and awareness raising/ IEC materials (I0000 Leaflets)

Awareness raising campaign/ orientation training in the schools among 50 teachers and 1500 students on Rabies, its prevention and treatment

Practical demonstration of first-aid treatment of dog bite

Film how (once in each class) to

disseminate the knowledge among school children on Rabies, dog bite, its prevention and treatment..

Post KAP study on Rabies, its prevention

and treatment among 200 students (40

students from each class )

Data editing, entry of 400 data, analysis in

SPSS soft ware

Report writing and submission $\times \times x$

$\times \quad \times$

$\times \quad X$

$x \quad x$ $X$

$\mathrm{X}$ X 


\section{Observations and results}

\section{Demographic characteristics}

Rabies status of pre and post KAP study: In total 400 data have collected by IACAB data collector team which is divided by Pre and Post KAP study. Both studies have taken equal number of data 200 only from two selected school by using $50.0 \%$ Pre KAP and $50.0 \%$ Post KAP purposively selection criteria on aforesaid study (Table 2).

School type of respondents by pre and post KAP study: Both from Zinzira Residential School and Nawaz Ali Ideal School have taken equal amount of 100 students that are shows to table below for pre and post KAP study. Total $100+100=200$ sample have taken by judgment sampling method for pre and post KAP study in order to $50 \%$ ratio sample size scale. 200 samples have taken for pre KAP and post KAP study respectively so that the result would be easy to follow by comparable strategy (Table 3 ).

Population of age group by pre and post KAP study: Population age group indicates the level of age from 10 up to 16 . We have consider the initial basic school going age are 5 years so that if we have added Age 5+level 5=10, up to Age 5+ Level $12=17$ years then we get the age of samples (students) such that 12 years aged students are $27.0 \%$, and $34.0 \%$ for pre and post KAP study respectively, Moreover 10 years old of students $2.5 \%$ and $10.5 \%$ also 16 years old of students are $0.5 \%$ and $0.0 \%$ for pre and post KAP study respectively (Table 4 ).

Respondents in education level by pre and post KAP study: Education level of respondents means that how many of students have been studying from class six up to Class Ten by our collected data. We have taken the data from secondary school going students and the result of table bellow indicates that $26 \%$ students of class 7 for pre KAP study and 26\% students of Class 8 for post KAP study that indicates the high percentage of the table below. Moreover the lowest rate of education level is $12 \%$ and $13.5 \%$ of class 10 for pre and post KAP study respectively. The percentage of other classes of students is as usual (Table 5).

Table 2 Distribution of study population according to pre and post-KAP data collection

\begin{tabular}{lll}
\hline Study Type & Frequency & Percent \\
\hline Pre KAP Study & 200 & 50 \\
Post KAP Study & 200 & 50 \\
Total & 400 & 100
\end{tabular}

Table 3 Distribution of Study population according to school

\begin{tabular}{lll}
\hline Name of Sample & Zinzira R/S & Nawaz Ali I/S \\
\hline Pre KAP Study & $100(50.0 \%)$ & $100(50.0 \%)$ \\
Post KAP Study & $100(50.0 \%)$ & $100(50.0 \%)$ \\
\hline Total & $\mathbf{2 0 0 ( 1 0 0 . 0 \% )}$ & $\mathbf{2 0 0 ( 1 0 0 . 0 \% )}$
\end{tabular}

Table 4 Distribution of study population according to age of the students

\begin{tabular}{|c|c|c|c|}
\hline Age & Pre KAP Study & Post KAP Study & Total \\
\hline 10Yrs & $5(2.5 \%)$ & $21(10.5 \%)$ & $26(6.5 \%)$ \\
\hline IIYrs & $33(16.5 \%)$ & $5 \mathrm{I}(25.5 \%)$ & $84(21.0 \%)$ \\
\hline 12 Yrs & $54(27.0 \%)$ & $68(34.0 \%)$ & $122(30.5 \%)$ \\
\hline 13 Yrs & $42(21.0 \%)$ & $34(17.0 \%)$ & $76(19.0 \%)$ \\
\hline 14 Yrs & $44(22.0 \%)$ & $17(8.5 \%)$ & $61(15.2 \%)$ \\
\hline 15 Yrs & $21(10.5 \%)$ & $9(4.5 \%)$ & $30(7.5 \%)$ \\
\hline 16 Yrs & $\mathrm{I}(0.5 \%)$ & $0(0.0 \%)$ & $\mathrm{I}(0.25 \%)$ \\
\hline Total & $200(100.0 \%)$ & $200(100.0 \%)$ & $400(100.0 \%)$ \\
\hline
\end{tabular}

Table 5 Distribution of study population according to educational status

\begin{tabular}{llll}
\hline Educational Status & Pre KAP Study & Post KAP Study Total \\
\hline Class 6 & $38(19.0 \%)$ & $47(23.5 \%)$ & $85(21.25 \%)$ \\
Class 7 & $52(26.0 \%)$ & $37(18.5 \%)$ & $89(22.25 \%)$ \\
Class 8 & $49(24.5 \%)$ & $52(26.0 \%)$ & $101(25.25 \%)$ \\
Class 9 & $37(18.5 \%)$ & $37(18.5 \%)$ & $74(18.5 \%)$ \\
Class 10 & $24(12.0 \%)$ & $27(13.5 \%)$ & $51(12.75 \%)$ \\
\hline Total & $\mathbf{2 0 0 ( 1 0 0 . 0 \% )}$ & $\mathbf{2 0 0}(100.0 \%)$ & $\mathbf{4 0 0}(100.0 \%)$ \\
\hline
\end{tabular}

\section{Knowledge about rabies prevention}

Household level of gender status by pre and post KAP study: The ratio of male and female students are $49.5 \%$ and $50.5 \%$ for pre KAP study also male $45 \%$ and female $55 \%$ for post KAP study in the household level of gender status table below. The following results indicate male students decreased and female students increased in the pre and post KAP studies respectively (Table 6).

Household level of religion status by pre and post KAP study: The height ratio of religion status are Muslim students $98.5 \%$ for pre and post KAP study and rest of percentage are others in the table below. So majority percent of Muslims are living this region (Table 7).

Household level of awareness on rabies by pre and post KAP study: The Table bellow shows that $60.5 \%$ respondents (students) are knows about rabies and $39.5 \%$ are not for Pre KAP study where as $92 \%$ are knows about rabies and $8 \%$ are not for post KAP study. This result means that respondents have been developing the awareness by training their respective trained up class teachers is $31.5 \%$ (Table 8).

Household level of knowledge about rabies by pre and post KAP study: The respondents explained the rabies exactly indicates full knowledge, partially explained indicate partial knowledge. About $45.0 \%$ respondents (students) explained the rabies such that rabies is a dog bitted virus that means full knowledge for pre KAP study, similarly $85.5 \%$ respondents have a full knowledge about rabies for post KAP study. So that knowledge of rabies increases from pre to post KAP study is $40.5 \%$ but other indicators decreased in the table below Table 9.

Table 6 Distribution of study population according to sex

\begin{tabular}{llll}
\hline Gender & Pre KAP Study & Post KAP Study & Total \\
\hline Male & $99(49.5 \%)$ & $90(45.0 \%)$ & $189(47.25 \%)$ \\
Female & $101(50.5 \%)$ & $110(55.0 \%)$ & $211(52.75 \%)$ \\
\hline Total & $\mathbf{2 0 0}(100.0 \%)$ & $\mathbf{2 0 0}(100.0 \%)$ & $\mathbf{4 0 0}(\mathbf{1 0 0 . 0 \% )}$ \\
\hline
\end{tabular}

Table 7 Distribution of study population according to religion

\begin{tabular}{llll}
\hline Religion & Pre KAP Study & Post KAP Study & Total \\
\hline Muslim & $197(98.5 \%)$ & $197(98.5 \%)$ & $394(98.5 \%)$ \\
Christian & $1(0.5 \%)$ & $0(0.0 \%)$ & $1(0.25 \%)$ \\
Buddhist & $0(0.0 \%)$ & $0(0.0 \%)$ & $0(0.0 \%)$ \\
Hindu & $2(1.0 \%)$ & $3(1.5 \%)$ & $5(1.25 \%)$ \\
\hline Total & $\mathbf{2 0 0 ( 1 0 0 . 0 \% )}$ & $\mathbf{2 0 0}(100.0 \%)$ & $\mathbf{4 0 0 ( 1 0 0 . 0 \% )}$ \\
\hline
\end{tabular}

Table 8 Distribution of study population according to know about rabies

\begin{tabular}{llll}
\hline Know about Rabies & Pre KAP Study & Post KAP Study & Total \\
\hline Yes & $121(60.5 \%)$ & $184(92.0 \%)$ & $305(76.25 \%)$ \\
No & $79(39.5 \%)$ & $16(8.0 \%)$ & $95(23.75 \%)$ \\
\hline Total & $\mathbf{2 0 0}(100.0 \%)$ & $\mathbf{2 0 0}(100.0 \%)$ & $\mathbf{4 0 0}(100.0 \%)$ \\
\hline
\end{tabular}

Table 9 Distribution of study population according to explain rabies

\begin{tabular}{|c|c|c|c|}
\hline Explain Rabies & Pre KAP Stud & y Post KAP Study & Total \\
\hline Not applicable & $78(39.0 \%)$ & $17(8.5 \%)$ & $95(23.75 \%)$ \\
\hline Virus affected disease & $90(45.0 \%)$ & $|7|(85.5 \%)$ & $26 I(65.25 \%)$ \\
\hline Rabbit dog affected disease & $21(10.5 \%)$ & $9(5.2$ & $30(7.5 \%)$ \\
\hline Ignore & $\mathrm{II}(5.5 \%)$ & $3(2.75 \%)$ & $14(3.5 \%)$ \\
\hline Total & $200(100.0 \%)$ & $200(100.0 \%)$ & $400(100.0 \%)$ \\
\hline
\end{tabular}




\section{Prevention from rabies}

Awareness level of respondents about prevention of rabies by pre \& post KAP study: About $60.5 \%$ respondents say yes about prevention of rabies for pre KAP study, similarly $92 \%$ respondents say the same answers in same questions. So the awareness about prevention of rabies is increased $31.5 \%$ from pre to post KAP study. Another way the negative answers no is soundly decreased from pre to post KAP study (Table 10).

Knowledge level of respondents about prevention of rabies by pre \& post KAP study: Rabies must be prevented by vaccine and medical treatment. Such upon the indicators remark $29 \%$ respondent's answers about prevention of rabies by vaccine for pre KAP and $64 \%$ given same answers for post KAP study, which indicates the increases of knowledge about prevention of rabies $35 \%$ from pre to post KAP study and other results are calculate by percentage in table below Table 11 .

Knowledge level of respondents about rabbit spread by pre \& post KAP study: Which animals can spread rabies in a person- the answer is that Dog $73 \%$ in pre KAP, $51.5 \%$ in post KAP study, Cow $0 \%$ and $0.5 \%$, Jackal $2.5 \%$ and $0.5 \%$, Monkey $0.5 \%$ and $0 \%$, Mongoose $0.5 \%$ and $0 \%$, also all of the pet animals that are mentioned above are $23 \%$ and $48 \%$ for pre and post KAP study respectively, which indicates that knowledge level of respondents about rabbit spread by dog is decreased $21.5 \%$ but the result is increased $25 \%$ spread by other pet animals in the table below Table 12 .

Awareness level of respondents of pet animals by pre \& post KAP study: The question is that can another pet animals get RabiesThe answers yes $48 \%$ for pre KAP and $73.5 \%$ for post KAP study respectively, which denotes the another pet animals get rabies awareness is build up from pre KAP to post KAP study $25.5 \%$. The remaining $52 \%$ and $26.5 \%$ respondents have given the negative responses respectively (Table 13).

Knowledge level of other pet animal by pre \& post KAP study: Another pet animals that can get rabies is Cow $11 \%$ and $7 \%$, Goat $5 \%$ and $2 \%$, Buffalo $4 \%$ and $2.5 \%$, horse $1.5 \%$ and $2 \%$, all of them that are mentioned in the questioned $27 \%$ and $60.5 \%$ for pre KAP and post KAP study respectively which indicates the average knowledge have developed than pre to post KAP study on rabid pet animals (Table 14)

Awareness level of respondents about rabbit dog by pre \& post KAP study: Awareness level of respondents about Rabbit Dog by pre \& post KAP study $83.5 \%$ and $95.5 \%$ yes, $16.5 \%$ and $4.5 \%$ no, respectively which indicates awareness $12 \%$ increased within the pre and post KAP study within time interval (Table 15).

Attitude level of respondents on the behave of rabid dog by pre \& post KAP study: Attitude level of respondents behaves of rabid dog defined by yes and/or not. Wants to bite a dog of respondents attitude is increase about $51 \%$ to $74.5 \%$, Wants to bite anything is decrease from $31.5 \%$ to $17 \%$, behave ferocious is decrease from $17 \%$ to $8 \%$ and ignorance is constant within the time interval for pre and post KAP study respectively. Finally the respondents (students) are benefitted by KAP study and training sessions. Otherwise percentage of ignorance dramatically has constant for both KAP study activities (Table 16)

Knowledge level of respondents be happened after rabbit bite by pre \& post Kap study: Knowledge level of respondents after rabid bite be get death are $53 \%$ and $89.5 \%$, be get a rabid $26 \%$ and $6 \%$, be get a mad $20.5 \%$ and $4 \%$, ignorance 0.5 and same respectively.
So we conclude that knowledge of respondent on rabid patient get death have increased significantly $36.5 \%$ for pre to post KAP study by IACIB life skill development project on rabies (Table 17).

Awareness level of respondent about death of rabbit patient by pre \& post KAP study: Awareness level of respondent about death of rabid patient is denoted by Yes and/or No $64.5 \%$ and $85 \%$ and $/$ or $35.5 \%$ and $15 \%$ for pre\& post KAP study respectively. So the respondent's awareness increased $20.5 \%$ by the life skill training project on rabies (Table 18).

Knowledge level of respondent about nursing after rabbit bite by pre \& post KAP Study: Knowledge level of respondent about nursing after rabbit bite is wash by hygiene soap or save loan $26 \%$ and $69 \%$, treatment by a doctor $68.5 \%$ and $28 \%$, taking vaccine $4 \%$ and $3 \%$, also ignore $1 \%$ and less by pre to post KAP study respectively. So the nursing knowledge of patient is strongly established especially hygiene soap and save loan by the project activities (Table 19).

Table 10 Distribution of study population according to knowledge about rabies

\begin{tabular}{|c|c|c|c|}
\hline Know about Rabies & Pre KAP S & y Post KAP Study & Total \\
\hline Yes & $121(60.5 \%)$ & $184(92.0 \%)$ & $305(76.25 \%)$ \\
\hline No & $79(39.5 \%)$ & $16(8.0 \%)$ & $95(23.75 \%)$ \\
\hline Total & $200(100.0 \%$ & $200(100.0 \%)$ & $400(100.0 \%)$ \\
\hline
\end{tabular}

Table II Distribution of study population according to knowledge of prevention

\begin{tabular}{llll}
\hline Knowledge of Prevention Pre KAP Study Post KAP Study Total \\
\hline Not applicable & $49(24.5 \%)$ & $32(16.0 \%)$ & $81(20.25 \%)$ \\
ByVaccine & $58(29.0 \%)$ & $128(64.0 \%)$ & $186(46.5 \%)$ \\
By treatment & $48(24.0 \%)$ & $33(16.5 \%)$ & $81(20.25 \%)$ \\
Ignore & $45(22.5 \%)$ & $7(3.5 \%)$ & $52(13.0 \%)$ \\
\hline Total & $\mathbf{2 0 0}(100.0 \%)$ & $\mathbf{2 0 0}(100.0 \%)$ & $\mathbf{4 0 0}(100.0 \%)$ \\
\hline
\end{tabular}

Table 12 Distribution of study population according to knowledge about rabid pet

\begin{tabular}{|c|c|c|c|}
\hline $\begin{array}{l}\text { Knowledge about } \\
\text { Rabid Pet }\end{array}$ & Pre KAP Study & Post KAP Study & Total \\
\hline Dog & |46(73.0\%) & $103(51.5 \%)$ & $249(62.25 \%)$ \\
\hline Cat & $0(0.0 \%)$ & $0(0.0 \%)$ & $0(0.0 \%)$ \\
\hline Jackal & $5(2.5 \%)$ & $0(0.0 \%)$ & $5(1.25 \%)$ \\
\hline Monkey & $\mathrm{I}(0.5 \%)$ & $0(0.0 \%)$ & $\mathrm{I}(0.25 \%)$ \\
\hline Mongoose & $\mathrm{I}(0.5 \%)$ & $0(0.0 \%)$ & $\mathrm{I}(0.25 \%)$ \\
\hline Cattle & $\mathrm{I}(0.5 \%)$ & $\mathrm{I}(0.5 \%)$ & $2(0.5 \%)$ \\
\hline All of the Above & $46(23.0 \%)$ & $96(48.0 \%)$ & I42(35.5\%) \\
\hline Total & $200(100.0 \%)$ & $200(100.0 \%)$ & $400(100.0 \%)$ \\
\hline
\end{tabular}

Table 13 Distribution of study population according to knowledge about other pet animals

\begin{tabular}{|c|c|c|c|}
\hline $\begin{array}{l}\text { Knowledge about } \\
\text { Other Pet }\end{array}$ & Pre KAP Study & Post KAP Study & Total \\
\hline Yes & $96(48.0 \%)$ & $147(73.5 \%)$ & $243(60.75 \%)$ \\
\hline No & $104(52.0 \%)$ & $53(26.5 \%)$ & I57(39.25\%) \\
\hline Total & $200(100.0 \%)$ & $200(100.0 \%)$ & $400(100.0 \%)$ \\
\hline
\end{tabular}

Table 14 Distribution of study population according to knowledge about rabid pet

\begin{tabular}{llll}
\hline $\begin{array}{l}\text { Explain Other Pet } \\
\text { Animals }\end{array}$ & \multicolumn{2}{l}{ Pre KAP Study Post KAP Study Total } \\
\hline Not applicable & $103(51.5 \%)$ & $52(26.0 \%)$ & $155(38.75 \%)$ \\
Cow & $22(11.0 \%)$ & $14(7.0 \%)$ & $36(9.0 \%)$ \\
Buffalos & $10(5.0 \%)$ & $4(2.0 \%)$ & $14(3.5 \%)$ \\
Goat & $8(4.0 \%)$ & $5(2.5 \%)$ & $13(3.25 \%)$ \\
Horse & $3(1.5 \%)$ & $4(2.0 \%)$ & $7(1.75 \%)$ \\
All of the above & $54(27.0 \%)$ & $121(60.5 \%)$ & $175(43.75 \%)$ \\
\hline Total & $\mathbf{2 0 0 ( 1 0 0 . 0 \% )}$ & $\mathbf{2 0 0 ( 1 0 0 . 0 \% )}$ & $\mathbf{4 0 0 ( 1 0 0 . 0 \% )}$ \\
\hline
\end{tabular}


Table I 5 Distribution of study population according to listen about rabid dog

\begin{tabular}{llll}
\hline Listen about Rabid & \multicolumn{3}{l}{ Pre KAP Study } \\
Dog
\end{tabular}

Table 16 Distribution of study population according to behave of rabid dog

\begin{tabular}{llll}
\hline Behave of Rabid Dog & Pre KAP Study Post KAP Study & Total \\
\hline Not applicable & $0(0.0 \%)$ & $0(0.0 \%)$ & $0(0.0 \%)$ \\
Wants to bite a man & $102(5 I .0 \%)$ & $149(74.5 \%)$ & $25 \mathrm{I}(62.75 \%)$ \\
Wants to bite anything & $63(31.5 \%)$ & $34(17.0 \%)$ & $97(24.25 \%)$ \\
Behave ferocious & $34(17.0 \%)$ & $16(8.0 \%)$ & $50(12.5 \%)$ \\
Ignore & I (0.5\%) & I (0.5\%) & $2(0.5 \%)$ \\
\hline Total & $\mathbf{2 0 0}(100.0 \%)$ & $\mathbf{2 0 0}(100.0 \%)$ & $\mathbf{4 0 0}(100.0 \%)$ \\
\hline
\end{tabular}

Table 17 Distribution of study population according to be happened after rabid bite

\begin{tabular}{llll}
\hline $\begin{array}{l}\text { Be Happened after } \\
\text { Rabid Bite }\end{array}$ & \multicolumn{3}{l}{ Pre KAP Study Post KAP Study Total } \\
\hline Be happened a death & I06(53.0\%) & I79(89.5\%) & $285(7 \mid .25 \%)$ \\
Be makes a rabid & $52(26.0 \%)$ & $12(6.0 \%)$ & $64(16.0 \%)$ \\
Be makes a mad & $4 I(20.5 \%)$ & $8(4.0 \%)$ & $49(12.25 \%)$ \\
Ignore & I(0.5\%) & I (0.5\%) & $2(0.5 \%)$ \\
\hline Total & $\mathbf{2 0 0}(100.0 \%)$ & $\mathbf{2 0 0}(100.0 \%)$ & $\mathbf{4 0 0}(100.0 \%)$ \\
\hline
\end{tabular}

Table 18 Distribution of study population according to be death after rabid patient

\begin{tabular}{llll}
\hline $\begin{array}{l}\text { Be Death after } \\
\text { Rabid Patient }\end{array}$ & \multicolumn{2}{l}{ Pre KAP Study Post KAP Study Total } \\
\hline Yes & \multicolumn{1}{l}{ I29(64.5\%) } & $170(85.0 \%)$ & $299(74.75 \%)$ \\
No & $71(35.5 \%)$ & $30(15.0 \%)$ & $101(25.25 \%)$ \\
\hline Total & $\mathbf{2 0 0}(100.0 \%)$ & $\mathbf{2 0 0}(100.0 \%)$ & $\mathbf{4 0 0}(100.0 \%)$ \\
\hline
\end{tabular}

Table 19 Distribution of study population according to nursing after bitted patient

\begin{tabular}{|c|c|c|}
\hline $\begin{array}{l}\text { Nursing after Bitted } \\
\text { Patient }\end{array}$ & Pre KAP Study & Post KAP Study Total \\
\hline Wash by a hygiene soap & $52(26.0 \%)$ & $138(69.0 \%)$ \\
\hline $\begin{array}{l}\text { Go to a doctor by } \\
\text { treatment }\end{array}$ & $137(68.5 \%)$ & $56(28.0 \%)$ \\
\hline Taking Vaccine & $9(4.5 \%)$ & $6(3.0 \%)$ \\
\hline Ignore & $2(1.0 \%)$ & $0(0.0 \%)$ \\
\hline Total & $200(100.0 \%)$ & $200(100.0 \%)$ \\
\hline
\end{tabular}

Knowledge and practice about rabies by pre and post KAP study

Awareness level of respondents about afraid of dog for rabbit by pre \& post KAP study:Awareness level of respondents about afraid of dog is Yes $63.5 \%$ and $61.5 \%$ and /or No $36.5 \%$ and $38.5 \%$ for rabbit by pre \& post KAP study. So the awareness is soundly developed by the study (Table 20).

Knowledge level of respondents for why afraid of dog by pre \& post KAP study: Knowledge level of Respondents for why afraid of dog for not applicable is increase from $30.5 \%$ to $38 \%$, may be bite a man is decreased from $8.0 \%$ to $5.5 \%$, may be made a rabies is decrease $60 \%$ to $56 \%$ and ignorance is decrease from $1.5 \%$ to $0.5 \%$ by pre \& post KAP study respectively. The total result represents to build up knowledge upon why afraid of respondents of dog (Table 21).

Practice level of respondents for how to face pet dogs in neighbor by pre \& post KAP study: Practice level of respondents for how to face pet dogs in neighbor still stand by $13.55 \%$ and $69.5 \%$, avoid dog $82.5 \%$ \& $24.5 \%$, run away $3 \%$ and $1 \%$, climb up tree $1 \%$ \& $5 \%$ also ignorance $0 \%$ and $0 \%$ respectively for pre- and post-KAP study, i.e. practice level of respondents have increased after training of school children on rabies (Table 22).

Practice level of respondents for domestic pet dog by pre \& post KAP study: Every respondent (students) of KAP study replies on the domestic pet dog have or not. The results is that yes $21 \%$ \& $24 \%$ also no $79 \% \& 76 \%$ for pre and post KAP study i.e. the major percentage of dog are floating in our society that require a pet management (Table 23).

Practice level of Respondents for how number of domestic pet dog by pre- and post-KAP study: The previous questions reflect the same answer in the following context below. The major percentage of population such that $75.0 \%$ and $76.5 \%$ for pre and post KAP study respectively does not involved in pet dog management. The minor percentage of population like $19.5 \%$ and $22.5 \%$ have has 1 to 3 pet dogs domestically for pre and post KAP study respectively (Table 24).

Awareness level of respondents for having any puppies by pre \& post KAP study: Awareness level of respondents for having any puppies by pre \& post KAP study was recorded. In pre-KAP study $22(11.0 \%)$ students gave the positive responses regarding the presence of puppies in their house and the rest $178(89.0 \%)$ students replied negative. In post-KAP study $18(9.0 \%)$ students gave the positive response and the rest $182(91.0 \%)$ students gave negative response (Table 25).

Practice level of respondents for domestic puppies by pre $\&$ post KAP study: Practice level of respondents for domestic puppies was recorded by pre \& post KAP study. A number of 360(90.0\%) students gave the responses regarding the absence of puppies in their house (Table 26).

Table 20 Distribution of study population according to afraid of dog

\begin{tabular}{|c|c|c|}
\hline About Afraid of Dog & Pre KAP Study & Post KAP Study Total \\
\hline Yes & $127(63.5 \%)$ & $123(6 \mid .5 \%)$ \\
\hline No & $73(36.5 \%)$ & $77(38.5 \%)$ \\
\hline Total & $200(100.0 \%)$ & $200(100.0 \%)$ \\
\hline
\end{tabular}

Table 2I Distribution of study population according to the reason of afraid

\begin{tabular}{llll}
\hline Reason of Afraid & Pre KAP Study & Post KAP Study Total \\
\hline Not applicable & $6 \mathrm{I}(30.5 \%)$ & $76(38.0 \%)$ \\
May be bite a man & $16(8.0 \%)$ & $\mathrm{I}(15.5 \%)$ & \\
May be made a rabies & $120(60.0 \%)$ & $\mathrm{I} \mid 2(56.0 \%)$ & \\
Ignore & $3(1.5 \%)$ & $\mathrm{I}(0.5 \%)$ & \\
\hline Total & $\mathbf{2 0 0}(100.0 \%)$ & $\mathbf{2 0 0}(100.0 \%)$ & $\mathbf{4 0 0}(\mathbf{1 0 0 . 0} \%)$ \\
\hline
\end{tabular}

Table 22 Distribution of study population according to behave of rabid dog

\begin{tabular}{llll}
\hline Behave of Dog & Pre KAP Study & Post KAP Study & Total \\
\hline Still stand by & $27(13.5 \%)$ & $139(69.5 \%)$ & \\
Avoid the dog & $165(82.5 \%)$ & $49(24.5 \%)$ & \\
Run Away & $6(3.0 \%)$ & $2(1.0 \%)$ & \\
Climb up tree & $2(1.0 \%)$ & $10(5.0 \%)$ & \\
Ignore & $0(0.0 \%)$ & $0(0.0 \%)$ & \\
\hline Total & $\mathbf{2 0 0}(100.0 \%)$ & $\mathbf{2 0 0}(100.0 \%)$ & $\mathbf{4 0 0}(\mathbf{1 0 0 . 0 \% )}$ \\
\hline
\end{tabular}

Table 23 Distribution of study population according to have you any pet dog

\begin{tabular}{llll}
\hline Pet Dog & Pre KAP Study & Post KAP Study Total \\
\hline Yes & $42(21.0 \%)$ & $48(24.0 \%)$ & \\
No & $158(79.0 \%)$ & $152(76.0 \%)$ & \\
\hline Total & $\mathbf{2 0 0 ( 1 0 0 . 0 \% )}$ & $\mathbf{2 0 0}(100.0 \%)$ & $\mathbf{4 0 0 ( 1 0 0 . 0 \% )}$ \\
\hline
\end{tabular}


Table 24 Distribution of study population according to number of pet

\begin{tabular}{|c|c|c|c|}
\hline Number of Pet & Pre KAP Study & Post KAP Study & Total \\
\hline Not applicable & $150(75.0 \%)$ & $153(76.5 \%)$ & \\
\hline I to 3 & $39(19.5 \%)$ & $45(22.5 \%)$ & \\
\hline 4 to 7 & II (5.5\%) & $2(1.0 \%)$ & \\
\hline 8 to 11 & $0(0.0 \%)$ & $0(0.0 \%)$ & \\
\hline Total & $200(100.0 \%)$ & $200(100.0 \%)$ & $400(100.0 \%)$ \\
\hline
\end{tabular}

Table 25 Distribution of study population according to any puppies'

\begin{tabular}{|c|c|c|}
\hline Any Puppies' & Pre KAP Study & Post KAP Study Total \\
\hline Yes & $22(11.0 \%)$ & $18(9.0 \%)$ \\
\hline No & I78(89.0\%) & |82(9|.0\%) \\
\hline Total & $200(100.0 \%)$ & $200(100.0 \%)$ \\
\hline
\end{tabular}

Table 26 Distribution of study population according to number of puppies

\begin{tabular}{llll}
\hline Number of Puppies & Pre KAP Study & Post KAP Study & Total \\
\hline Not applicable & I77(88.5\%) & $183(91.5 \%)$ & $360(90.0 \%)$ \\
I to 3 & $16(8.0 \%)$ & $13(6.5 \%)$ & $29(7.25 \%)$ \\
4 to 7 & $6(3.0 \%)$ & $4(2.0 \%)$ & $10(2.5 \%)$ \\
8 to II & I $(0.5 \%)$ & $0(0.0 \%)$ & $1(0.25 \%)$ \\
\hline Total & $\mathbf{2 0 0}(100.0 \%)$ & $\mathbf{2 0 0}(100.0 \%)$ & $\mathbf{4 0 0}(100.0 \%)$ \\
\hline
\end{tabular}

Availability of vaccine and knowledge of domestic dog

Knowledge level of respondents about birth of dog in a year by pre \& post KAP study: Knowledge level of respondents about birth of dog in a year was evaluated in pre \& post KAP study. Majority have said that 1 time per year; however, 3 or above times per year was in $44(22.0 \%)$ in pre-KAP study. However, the maximum were responded in post-KAP than pre-KAP study (Table 27).

Awareness level of respondents about Birth how no of puppies at a time by pre \& post KAP study: Awareness level of Respondents about Birth how no of puppies at a time was evaluated in pre \& post KAP study. Birth how no of puppies was important to know. In this context $178(89.0 \%)$ students were negative response. However, the maximum were responded in post-KAP than pre-KAP study (Table 28).

Knowledge level of respondents about birth how many puppies at a time by pre \& post KAP study: Knowledge level of Respondents about Birth how many puppies at a time was evaluated in pre \& post KAP study. In this context $117(58.5 \%)$ students were said 1 times per year. However, the maximum were responded in post-KAP than preKAP study (Table 29).

Awareness level of respondents about vaccinate by pre \& post KAP study: Awareness level of respondents about vaccinate was evaluated in pre \& post KAP study. In this context $172(86.0 \%)$ students were negative response. However, the maximum were responded in postKAP than pre-KAP study (Table 30 ).

Knowledge level of respondents about vaccinate by pre \& post KAP study: Knowledge level of respondents about vaccinate was evaluated in pre \& post KAP study. In this context $172(86.0 \%)$ students were not applicable. However, the maximum were responded in post-KAP than pre-KAP study (Table 31 ).

Awareness level of respondent about walking dog on foot path by pre \& post KAP study: Awareness level of Respondent about walking dog on foot-path was evaluated in pre \& post KAP study. In this context $161(80.5 \%)$ students were positive response. However, the maximum were responded in post-KAP than pre-KAP study (Table 32).
Knowledge level of respondents how many walking dog on foot path by pre \& post KAP study: Knowledge level of respondents how many walking dog on foot path was evaluated in pre \& post KAP study. In this context 127(63.5\%) students were said 1 to 3 . However, the maximum were responded in post-KAP than pre-KAP study (Table 33).

Awareness of respondents for killing the dog on the way by pre \& post KAP study: Awareness of respondents for killing the dog on the way was evaluated in pre \& post KAP study. Killing of dog was dangerous and these dogs usually more aggressive. In this context $171(85.5 \%)$ students were negative response. However, the maximum were responded in post-KAP than pre-KAP study (Table 34).

Knowledge of respondents for killing the dog on the way by pre $\&$ post KAP study: Knowledge of respondents for killing the dog on the way was evaluated in pre \& post KAP study. In this context 35(17.5\%) students were said ferocious. However, the maximum were responded in post-KAP than pre-KAP study (Table 35).

Practice of respondents for watching dog by pre \& post KAP study: Practice of respondents for watching dog was evaluated in pre \& post KAP study. Watching dog was dangerous and these dogs usually more aggressive. In this context $395(98.75 \%)$ students were negative response. However, the maximum were responded in postKAP than pre-KAP study (Table 36).

\section{Awareness program on the high school students}

Awareness level of respondents about disturb in sleeping dog by pre \& post KAP study: Awareness level of respondents about disturb in sleeping dog was evaluated in pre \& post KAP study. Disturb in sleeping dog was dangerous and these dogs usually more aggressive. In this context 395(98.75\%) students were negative response. However, the maximum were responded in post-KAP than pre-KAP study (Table 37).

Attitude level of respondents about sleeping dog by pre \& post KAP study: Attitude level of respondents about sleeping dog was evaluated in pre \& post KAP study. Sleeping dog was dangerous and these dogs usually more aggressive. In this context $273(68.25 \%)$ students were positive response. However, the majority students were responded in post-KAP than pre-KAP study (Table 38).

Awareness level of respondents about feeding dog by pre \& post KAP study: Awareness level of respondents about feeding dog was evaluated in pre \& post KAP study. Feeding dog was dangerous and these dogs usually more aggressive. In this context 396(99.0\%) students were negative response. However, the majority students were responded in post-KAP than pre-KAP study (Table 39).

Attitude level of respondents about feeding dog by pre \& post KAP study: Attitude level of Respondents about feeding dog was evaluated in pre \& post KAP study. Feeding dog was dangerous and these dogs usually more aggressive. In this context $280(70.0 \%)$ students were positive response. However, the maximum were responded in postKAP than pre-KAP study (Table 40).

Awareness level of respondents about eating dog by pre \& post KAP study: Awareness level of Respondents about eating dog was evaluated in pre \& post KAP study. Disturbance to eating dogs was dangerous and these dogs usually more aggressive to bit. In this context 397(99.27\%) students were negative response. However, the minor changes occurred in post-KAP than pre-KAP study (Table 41).

Attitude level of respondents about eating dog by pre \& post KAP study: Attitude level of Respondents about eating dog was evaluated 
in pre \& post KAP study. Eating dogs usually were more aggressive to bit. In this context $286(71.5 \%)$ students were positive response. However, the majority were responded in post-KAP than pre-KAP study (Table 42).

Knowledge or practice level of respondents for moving to scratch the dog by pre \& post KAP study: Knowledge or practice level of respondents about moving to scratch the dog was evaluated in pre \& post KAP study. Majority were responded that they were still stand up in $178(44.5 \%)$ students. Avoidance of the dog was reported by $200(50.0 \%)$ students. The majority were responded in pre-KAP which was decreased in post-KAP study (Table 43).

Awareness level of respondents for Govt. vaccination by pre \& post KAP study: Awareness level of students about the Govt. vaccination was evaluated and was found that 345(86.25\%) students knew about it and the rest 55(13.75\%) students unaware of it. However there was an improvement of post-KAP study in comparison with pre-KAP study (Table 44-48).

Table 27 Distribution of study population according to birth of dog in a year

\begin{tabular}{llll}
\hline Birth once a Year & Pre KAP Study & Post KAP Study Total \\
\hline Not applicable & $4(2.0 \%)$ & $9(4.5 \%)$ & \\
I times per year & $117(58.5 \%)$ & $140(70.0 \%)$ & \\
2 times per year & $35(17.5 \%)$ & $35(17.5 \%)$ & \\
3 or above times per year & $44(22.0 \%)$ & $16(8.0 \%)$ & \\
lgnore & $0(0.0 \%)$ & $0(0.0 \%)$ & \\
\hline Total & $\mathbf{2 0 0}(100.0 \%)$ & $\mathbf{2 0 0}(100.0 \%)$ & $\mathbf{4 0 0}(100.0 \%)$ \\
\hline
\end{tabular}

Table 28 Distribution of study population according to number of birth of puppies at a time

\begin{tabular}{llll}
\hline Have you any Puppies & Pre KAP Study Post KAP Study & Total \\
\hline Yes & $22(11.0 \%)$ & $18(9.0 \%)$ & 40 \\
No & $178(89.0 \%)$ & $182(91.0 \%)$ & 360 \\
\hline Total & $200(100.0 \%)$ & $200(100.0 \%)$ & $400(100.0 \%)$
\end{tabular}

Table 29 Distribution of study population according to number of birth in a year

\begin{tabular}{llll}
\hline $\begin{array}{l}\text { Number of Birth in } \\
\text { a Year }\end{array}$ & Pre KAP Study & Post KAP Study & Total \\
\hline Not applicable & $4(2.0 \%)$ & $9(4.5 \%)$ & 13 \\
I times per year & $117(58.5 \%)$ & $140(70.0 \%)$ & 257 \\
2 times per year & $35(17.5 \%)$ & $35(17.5 \%)$ & 70 \\
$\begin{array}{l}\text { 3 or above times per } \\
\text { year }\end{array}$ & $44(22.0 \%)$ & $16(8.0 \%)$ & 60 \\
lgnore & $0(0.0 \%)$ & $0(0.0 \%)$ & 0 \\
\hline Total & $\mathbf{2 0 0}(100.0 \%)$ & $\mathbf{2 0 0}(100.0 \%)$ & $\mathbf{4 0 0}(\mathbf{1 0 0 . 0} \%)$ \\
\hline
\end{tabular}

Table 30 Distribution of study population according to about vaccination

\begin{tabular}{|c|c|c|c|}
\hline About Vaccinate & Pre KAP Study & Y Post KAP Study & Total \\
\hline Yes & $28(\mid 4.0 \%)$ & $19(7.0 \%)$ & 47 \\
\hline No & I72(86.0\%) & $181(93.0 \%)$ & 353 \\
\hline Total & $200(100.0 \%)$ & $200(100.0 \%)$ & $400(100.0 \%)$ \\
\hline
\end{tabular}

Table 3I Distribution of study population according to reason of vaccination

\begin{tabular}{llll}
\hline Reason of Vaccination & Pre KAP Study & Post KAP Study & Total \\
\hline Not applicable & $172(86.0 \%)$ & $184(92.0 \%)$ & 356 \\
Govt. hospital & $12(6.0 \%)$ & $9(4.5 \%)$ & 21 \\
Non Govt. hospital & $12(6.0 \%)$ & $4(2.0 \%)$ & 16 \\
Ignore & $4(2.0 \%)$ & $3(1.5 \%)$ & 7 \\
\hline Total & $\mathbf{2 0 0 ( 1 0 0 . 0 \% )}$ & $\mathbf{2 0 0}(100.0 \%)$ & $\mathbf{4 0 0}(100.0 \%)$ \\
\hline
\end{tabular}

Table 32 Distribution of study population according to see walking of dog

\begin{tabular}{llll}
\hline \multicolumn{4}{l}{ To See Walking of Dog Pre KAP Study Post KAP Study Total } \\
\hline Yes & $161(80.5 \%)$ & $180(90.0 \%)$ & 341 \\
No & $39(19.5 \%)$ & $20(10.0 \%)$ & 59 \\
\hline Total & $\mathbf{2 0 0}(100.0 \%)$ & $\mathbf{2 0 0}(100.0 \%)$ & $\mathbf{4 0 0}(100.0 \%)$
\end{tabular}

Table 33 Distribution of study population according to see walking of dog

\begin{tabular}{llll}
\hline How many Walking & Pre KAP Study & Post KAP Study & Total \\
\hline Not applicable & $37(18.5 \%)$ & $19(9.5 \%)$ & \\
I to 3 & $127(63.5 \%)$ & $121(60.5 \%)$ & \\
4 to 7 & $34(17.0 \%)$ & $60(30.0 \%)$ & \\
8 to 1 I & $2(1.0 \%)$ & $0(0.0 \%)$ & \\
Ignore & $0(0.0 \%)$ & $0(0.0 \%)$ & \\
\hline Total & $\mathbf{2 0 0}(100.0 \%)$ & $\mathbf{2 0 0}(100.0 \%)$ & $\mathbf{4 0 0}(100.0 \%)$ \\
\hline
\end{tabular}

Table 34 Distribution of study population according to wouldn't be killed

\begin{tabular}{llll}
\hline Wouldn't be Killed & Pre KAP Study & Post KAP Study & Total \\
\hline Yes & $29(14.5 \%)$ & $25(12.5 \%)$ & 54 \\
No & $171(85.5 \%)$ & $175(87.5 \%)$ & 346 \\
\hline Total & $\mathbf{2 0 0}(100.0 \%)$ & $\mathbf{2 0 0}(\mathbf{1 0 0 . 0} \%)$ & $\mathbf{4 0 0 ( 1 0 0 . 0 \% )}$ \\
\hline
\end{tabular}

Table 35 Distribution of study population according to wouldn't be killed

\begin{tabular}{llll}
\hline Why be Killed & Pre KAP Study & Post KAP Study Total \\
\hline Not applicable & $152(76.0 \%)$ & $173(86.5 \%)$ \\
Harmful for health & $10(5.0 \%)$ & $6(3.0 \%)$ \\
Ferocious & $35(17.5 \%)$ & $19(9.5 \%)$ & \\
May be bite & $3(1.5 \%)$ & $2(1.0 \%)$ & \\
lgnore & $0(0.0 \%)$ & $0(0.0 \%)$ & \\
\hline Total & $\mathbf{2 0 0}(100.0 \%)$ & $\mathbf{2 0 0}(100.0 \%)$ & $\mathbf{4 0 0}(\mathbf{1 0 0 . 0 \% )}$ \\
\hline
\end{tabular}

Table 36 Distribution of study population according to wouldn't be killed

\begin{tabular}{|c|c|c|c|}
\hline $\begin{array}{l}\text { When Dog want to } \\
\text { Attract us }\end{array}$ & Pre KAP Study & Post KAP Study & Total \\
\hline Still stand up & $26(13.0 \%)$ & $169(84.5 \%)$ & $195(48.75 \%)$ \\
\hline Avoid the Dog & $165(82.5 \%)$ & $25(12.5 \%)$ & $190(47.5 \%)$ \\
\hline Run Away & $5(2.5 \%)$ & $\mathrm{I}(0.5 \%)$ & $6(1.5 \%)$ \\
\hline Climb up tree & $0(0.0 \%)$ & $0(0.0 \%)$ & $0(0.0 \%)$ \\
\hline Ignore & $4(2.0 \%)$ & $5(2.5 \%)$ & $9(2.25 \%)$ \\
\hline Total & $200(100.0 \%)$ & $200(100.0 \%)$ & $400(100.0 \%)$ \\
\hline
\end{tabular}

Table 37 Distribution of study population according to disturb in sleeping

\begin{tabular}{llll}
\hline Disturb in Sleeping & Pre KAP Study & Post KAP Study & Total \\
\hline Yes & $4(2.0 \%)$ & $\mathrm{I}(\mathrm{I} .0 \%)$ & $5(\mathrm{I} .25 \%)$ \\
No & $\mathrm{I} 96(98.0 \%)$ & $\mathrm{I} 99(99.0 \%)$ & $395(98.75 \%)$ \\
\hline Total & $\mathbf{2 0 0}(\mathbf{I 0 0 . 0} \%)$ & $\mathbf{2 0 0}(100.0 \%)$ & $\mathbf{4 0 0}(\mathbf{I 0 0 . 0} \%)$ \\
\hline
\end{tabular}

Table 38 Distribution of study population according to attitude about sleeping dog

\begin{tabular}{llll}
\hline $\begin{array}{l}\text { Attitude about } \\
\text { Sleeping Dog }\end{array}$ & Pre KAP Study & Post KAP Study & Total \\
\hline Yes & $\mathrm{II} 4(57.0 \%$ & $159(79.5 \%)$ & $273(68.25 \%)$ \\
No & $86(43.0 \%)$ & $4 I(20.5 \%)$ & $127(31.75 \%)$ \\
\hline Total & $\mathbf{2 0 0}(100.0 \%)$ & $\mathbf{2 0 0}(100.0 \%)$ & $\mathbf{4 0 0}(100.0 \%)$ \\
\hline
\end{tabular}

Table 39 Distribution of study population according to disturb in feeding

\begin{tabular}{llll}
\hline $\begin{array}{l}\text { Disturb in } \\
\text { Feeding }\end{array}$ & Pre KAP Study & Post KAP Study & Total \\
\hline Yes & $4(2.0 \%)$ & $0(0.0 \%)$ & $4(1.0 \%)$ \\
No & $196(98.0 \%)$ & $200(100.0 \%)$ & $396(99.0 \%)$ \\
\hline Total & $\mathbf{2 0 0}(100.0 \%)$ & $\mathbf{2 0 0}(100.0 \%)$ & $\mathbf{4 0 0}(100.0 \%)$ \\
\hline
\end{tabular}


Table 40 Distribution of study population according to about attitude about feeding dog

\begin{tabular}{llll}
\hline $\begin{array}{l}\text { Attitude about } \\
\text { Feeding Dog }\end{array}$ & Pre KAP Study & Post KAP Study & Total \\
\hline Yes & $122(61.0 \%)$ & $158(79.0 \%)$ & $280(70.0 \%)$ \\
No & $78(39.0 \%)$ & $42(21.0 \%)$ & $120(30.0 \%)$ \\
\hline Total & $\mathbf{2 0 0}(100.0 \%)$ & $\mathbf{2 0 0}(100.0 \%)$ & $\mathbf{4 0 0}(100.0 \%)$ \\
\hline
\end{tabular}

Table 4 I Distribution of study population according to disturb in eating

\begin{tabular}{llll}
\hline Disturb in Eating & Pre KAP Study & Post KAP Study & Total \\
\hline Yes & $2(1.0 \%)$ & $\mathrm{I}(0.5 \%)$ & $3(0.75 \%)$ \\
No & $198(99.0 \%)$ & $199(99.5 \%)$ & $397(99.27 \%)$ \\
\hline Total & $\mathbf{2 0 0}(100.0 \%)$ & $\mathbf{2 0 0}(100.0 \%)$ & $\mathbf{4 0 0}(100.0 \%)$
\end{tabular}

Table 42 Distribution of study population according to attitude about eating dog

\begin{tabular}{llll}
\hline $\begin{array}{l}\text { Attitude about } \\
\text { Eating Dog }\end{array}$ & Pre KAP Study & Post KAP Study & Total \\
\hline Yes & $123(61.5 \%)$ & $163(81.5 \%)$ & $286(71.5 \%)$ \\
No & $77(38.5 \%)$ & $37(18.5 \%)$ & $114(28.5 \%)$ \\
\hline Total & $200(100.0 \%)$ & $\mathbf{2 0 0}(100.0 \%)$ & $\mathbf{4 0 0}(100.0 \%)$ \\
\hline
\end{tabular}

Table 43 Distribution of study population according to move to scratch

\begin{tabular}{llll}
\hline $\begin{array}{l}\text { Move to } \\
\text { Scratch }\end{array}$ & $\begin{array}{l}\text { Pre KAP } \\
\text { Study }\end{array}$ & $\begin{array}{l}\text { Post KAP } \\
\text { Study }\end{array}$ & Total \\
\hline Still Stand UP & $15(7.5 \%)$ & $163(81.5 \%)$ & $178(44.5 \%)$ \\
Avoid the Dog & $175(87.5 \%)$ & $25(12.5 \%)$ & $200(50.0 \%)$ \\
Run away & $10(5.0 \%)$ & $3(1.5 \%)$ & $13(3.25 \%)$ \\
Climb the Tree & $0(0.0 \%)$ & $0(0.0 \%)$ & $0(0.0 \%)$ \\
Protect by Stick & $0(0.0 \%)$ & $2(1.0 \%)$ & $2(0.5 \%)$ \\
Ignore & $0(0.0 \%)$ & $7(3.5 \%)$ & $7(1.75 \%)$ \\
\hline Total & $\mathbf{2 0 0 ( 1 0 0 . 0 \% )}$ & $\mathbf{2 0 0}(100.0 \%)$ & $\mathbf{4 0 0}(100.0 \%)$
\end{tabular}

Table 44 Distribution of study population according to govt. vaccination

\begin{tabular}{llll}
\hline Govt.Vaccine & $\begin{array}{l}\text { Pre KAP } \\
\text { Study }\end{array}$ & $\begin{array}{l}\text { Post KAP } \\
\text { Study }\end{array}$ & Total \\
\hline Yes & $166(83.0 \%)$ & $179(89.5 \%)$ & $345(86.25 \%)$ \\
No & $34(17.0 \%)$ & $21(10.5 \%)$ & $55(13.75 \%)$ \\
\hline Total & 200(100.0\%) & $\mathbf{2 0 0}(100.0 \%)$ & $\mathbf{4 0 0}(100.0 \%)$ \\
\hline
\end{tabular}

Table 45 Association between the educational status and the knowledge about rabies

\begin{tabular}{|c|c|c|c|c|c|c|c|c|}
\hline \multirow{2}{*}{ Explain Rabies } & \multirow{2}{*}{ KAP Study } & \multicolumn{5}{|c|}{ Educational Status } & \multirow{2}{*}{ Total } & \multirow{2}{*}{$P$ value } \\
\hline & & Class 6 & Class 7 & Class 8 & Class 9 & Class 10 & & \\
\hline \multirow{3}{*}{ Not applicable } & Pre KAP & 22 & 21 & 17 & 13 & 5 & 78 & \multirow{2}{*}{0.428} \\
\hline & Post KAP & 8 & 4 & 4 & I & 0 & 17 & \\
\hline & Total & 30 & 25 & 21 & 14 & 5 & 95 & \multirow{3}{*}{0.216} \\
\hline \multirow{3}{*}{ Virus affected disease } & Pre KAP & 10 & 21 & 24 & 22 & 13 & 90 & \\
\hline & Post KAP & 38 & 29 & 45 & 34 & 25 & |7| & \\
\hline & Total & 48 & 50 & 69 & 56 & 38 & 261 & \multirow{4}{*}{0.624} \\
\hline \multirow{3}{*}{$\begin{array}{l}\text { Rabid dog affected } \\
\text { disease }\end{array}$} & Pre KAP & 2 & 5 & 7 & 2 & 5 & 21 & \\
\hline & Post KAP & 0 & 4 & 3 & 0 & 2 & 9 & \\
\hline & Total & 2 & 9 & 10 & 2 & 7 & 30 & \\
\hline \multirow{3}{*}{ Ignore } & Pre KAP & 4 & 5 & I & 0 & 1 & II & \multirow{2}{*}{0.055} \\
\hline & Post KAP & 1 & 0 & 0 & 2 & 0 & 3 & \\
\hline & Total & 5 & 5 & I & 2 & I & 14 & \multirow{4}{*}{$0.44 I$} \\
\hline \multirow{3}{*}{ Total } & Pre KAP & 38 & 52 & 49 & 37 & 24 & 200 & \\
\hline & Post KAP & 47 & 37 & 52 & 37 & 27 & 200 & \\
\hline & Total & 85 & 89 & 101 & 74 & 51 & 400 & \\
\hline
\end{tabular}

Table 46 Association between the Gender differences and the Knowledge of Prevention of Rabies

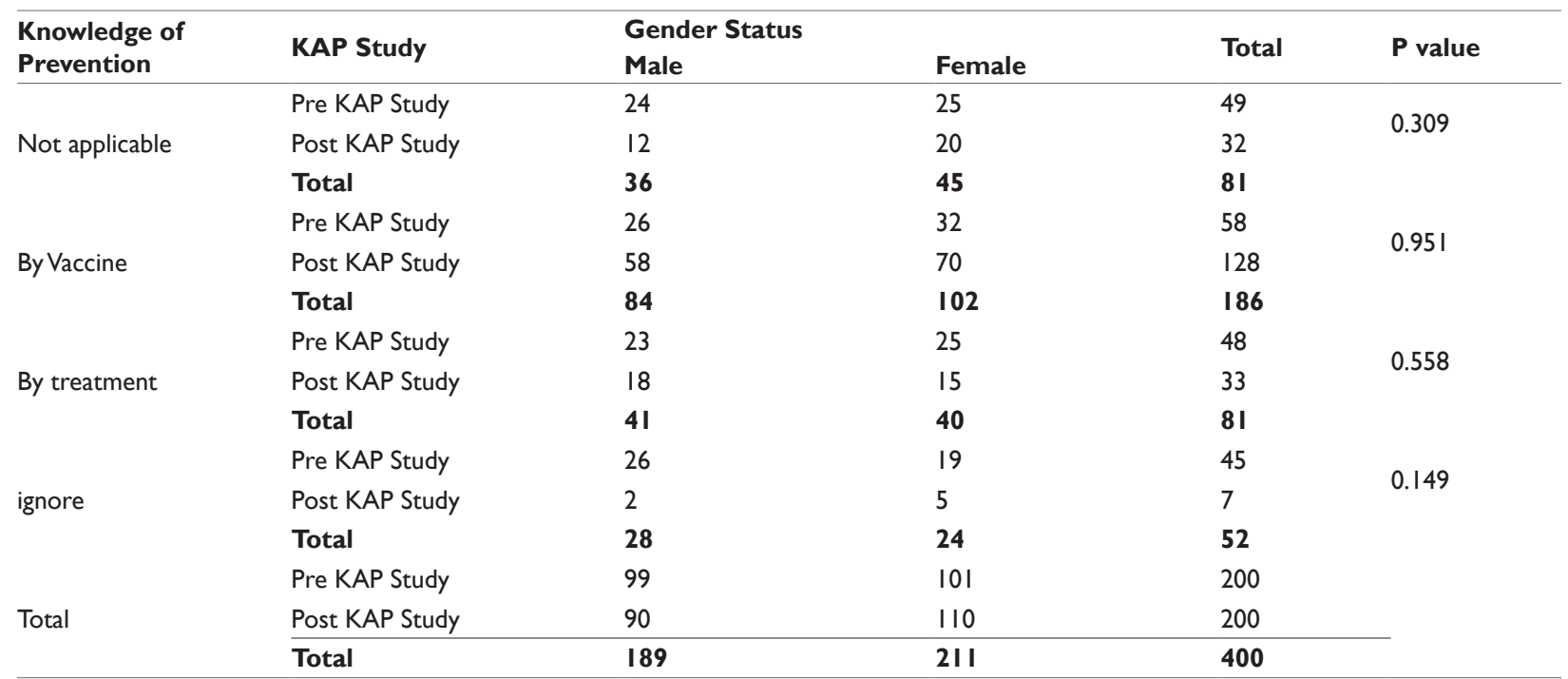


Table 47 Relationship between the Age differences of Student and the Knowledge about of Nursing after bitted patient

\begin{tabular}{|c|c|c|c|c|c|c|c|c|c|c|}
\hline \multirow{2}{*}{$\begin{array}{l}\text { Nursing after } \\
\text { Bitted Patient }\end{array}$} & \multirow{2}{*}{ KAP Study } & \multicolumn{7}{|c|}{ Age of Student (Years) } & \multirow{2}{*}{ Total } & \multirow{2}{*}{$P$ value } \\
\hline & & 10 & II & 12 & 13 & 14 & 15 & 16 & & \\
\hline \multirow{3}{*}{$\begin{array}{l}\text { Wash by a hygiene } \\
\text { soap, save loan }\end{array}$} & Pre KAP Study & 0 & 5 & 12 & 13 & 13 & 9 & & 52 & \\
\hline & Post KAP Study & 14 & 33 & 44 & 24 & 14 & 9 & & 138 & 0.001 \\
\hline & Total & 14 & 38 & 56 & 37 & 27 & 18 & & 190 & \\
\hline \multirow{3}{*}{$\begin{array}{l}\text { Go to a doctor by } \\
\text { treatment }\end{array}$} & Pre KAP Study & 5 & 24 & 40 & 25 & 30 & 12 & I & 137 & \\
\hline & Post KAP Study & 6 & 16 & 22 & 9 & 3 & 0 & 0 & 56 & 0.004 \\
\hline & Total & II & 40 & 62 & 34 & 33 & 12 & I & 193 & \\
\hline \multirow{3}{*}{ Taking Vaccine } & Pre KAP Study & 0 & 3 & 2 & 3 & I & & & 9 & \\
\hline & Post KAP Study & I & 2 & 2 & I & 0 & & & 6 & 0.608 \\
\hline & Total & I & 5 & 4 & 4 & I & & & 15 & \\
\hline \multirow{2}{*}{ Ignore } & Pre KAP Study & & I & & I & & & & 2 & \\
\hline & Total & & I & & I & & & & 2 & \\
\hline \multirow{3}{*}{ Total } & Pre KAP Study & 5 & 33 & 54 & 42 & 44 & 21 & I & 200 & \\
\hline & Post KAP Study & 21 & 51 & 68 & 34 & 17 & 9 & 0 & 200 & 0.0001 \\
\hline & Total & 26 & 84 & 122 & 76 & 61 & 30 & I & 400 & \\
\hline
\end{tabular}

Table 48 Association between the Knowledge about vaccination and Govt. vaccine

\begin{tabular}{|c|c|c|c|c|c|}
\hline Govt.Vaccine & KAP Study & $\begin{array}{l}\text { Abo } \\
\text { Yes }\end{array}$ & No & Total & $P$ value \\
\hline & Pre KAP Study & 23 & 143 & 166 & \\
\hline \multirow[t]{3}{*}{ Yes } & Post KAP Study & 18 & 161 & 179 & 0.276 \\
\hline & Total & 41 & 304 & 345 & \\
\hline & Pre KAP Study & 5 & 29 & 34 & \\
\hline \multirow[t]{3}{*}{ No } & Post KAP Study & I & 20 & 21 & 0.25 \\
\hline & Total & 6 & 49 & 55 & \\
\hline & Pre KAP Study & 28 & 172 & 200 & \\
\hline \multirow[t]{2}{*}{ Total } & Post KAP Study & 19 & 181 & 200 & 0.162 \\
\hline & Total & 47 & 353 & 400 & \\
\hline
\end{tabular}

\section{Discussion}

In order to discuss the current Rabies burden in Bangladesh, Rabies is a major public health issue, it is relatively under-reported disease. Despite the high human and animal death toll, no appropriate or adequate measures have so far been taken to address this issue properly. Lack of awareness, access to good quality and affordable post exposure human vaccines and unsafe dog population are the three determining factors of Rabies in Bangladesh. It is unfortunate that despite the availability of all tools and technology for human rabies prevention and dog rabies elimination, more than two thousand people die of rabies in Bangladesh every year, Bangladesh has the second highest rabies related death toll in the world.

Successful elimination of human rabies needs prevention of animal rabies, public awareness and people's access to low cost and high quality post exposure vaccines. Leaving any of these three components out of the equation will fail to deliver the desired results. The KAP study urged the Ministry of Health to declare Rabies as a priority disease and allocate necessary financial support through HNPSP (Health, Nutrition and Population Sector Programme) to fund the activities. Also it is suggested that Animal Birth Control (ABC) programme as it is practiced in many countries in the region including Sri Lanka, Nepal and India, Philippines with wonderful results.

In Bangladesh, in the hope of finding a quick solution to Rabies and overpopulation of stray dogs, the Local Government authorities resort to mass destruction of stray dogs only to discover that the destruction had to continue using government resources, year after year, with no end in sight. Dhaka City Corporation alone kills 70-80 dogs per day. Huge amount of government resources are allocated to killing these dogs every year. But dog culling is considered cruelty to animals worldwide and can have devastating social, economic and environmental affects in the country. So it is time to thinking an alternative and more humane and effective dog population management through an Animal Birth Control (ABC) and mass stray vaccination programme that would not only curb the stray population but will also effectively prevent spread of Rabies. The study also urged the Local Government to re-assess its existing pet registration policy to make it more affordable and accessible to the common people.

In light of the recommendations made by IACIB, the researcher assured that NGO, Private-Public partnership would look into this issue from a new perspective and will undertake Rabies control activities that are effective and promises a long term solution. As Rabies is a public health issue, it is the mandate of the Ministry of Health to lead this effort forward. However, successful implementation of a National Rabies Control Programme requires a multi-stakeholder approach with involvements of the Local Government Division, Department of Livestock, Pharmaceutical Companies, NGOs and Civil Society leaders.

\section{Conclusion}

In conclusion the school going children is very poor knowledge about the rabies virus regarding the transmission, clinical features and other related issues which is very much important for the prevention of rabies. Therefore the attitude and practice about rabies and the pet animals is not good during handling. However, the pre-KAP study result is improved after post-KAP study which reflects that proper education regarding the rabies virus is essential for the prevention as well the elimination of rabies virus.

\section{Summary}

School going children represents a future society of Bangladesh. Therefore, it is very important to know the information about the 
different diseases regarding their transmission, clinical features as well as the mode of prevention. Rabies is a preventable disease. In this regards the information about rabies among the school going children is very important. The purpose of the present study was to know the knowledge, attitude \& practice about rabies \& pet animals among school going children in Bangladesh. This study cross sectional descriptive type of observational study was conducted from February to December' 2014 for a period of 11 (Eleventh) month. A total number of 2 schools were selected by judgment sampling from Birulia and Savar Union Parishad under Savar Upozila of Dhaka district, where "Filaria and General Hospital" under IACIB is located. About two schools of students were interviewed from total 400 students selected by regular random basis judgments and cluster sampling covering five classes. All survey locations were selected from Union. But teachers, guardians, local formal or informal leaders, from nearby village or Schools where household survey was conducted have selected. In total 400 data have collected by IACAB data collector team which are divided by pre and post KAP study. Both studies have taken equal number of data 200 only from two selected school by using $50.0 \%$ Pre KAP and 50.0\% Post KAP purposively selection criteria on aforesaid study. Both from Zinzira Residential School and Nawaz Ali Ideal School have taken equal amount of 100 students that are shows to table below for pre and post KAP study. The ratio of male and female students are $49.5 \%$ and $50.5 \%$ for pre KAP study also male $45 \%$ and female $55 \%$ for post KAP study in the household level of gender status table below. About $60.5 \%$ respondents say yes about prevention of rabies for pre KAP study, similarly $92 \%$ respondents say the same answers in same questions. So the awareness about prevention of rabies is increased $31.5 \%$ from pre to post KAP study. Rabies must be prevented by vaccine and medical treatment. Such upon the indicators remark 29\% respondent's answers about prevention of rabies by vaccine for pre KAP and $64 \%$ given same answers for post KAP study, which indicates the increases of knowledge about prevention of rabies $35 \%$ from pre to post KAP study and other results are calculate by percentage in table below. Attitude level of respondents behaves of rabid dog defined by yes and/or not. Wants to bite a dog of respondents attitude is increase about $51 \%$ to $74.5 \%$, wants to bite anything is decrease from $31.5 \%$ to $17 \%$, behave ferocious is decrease from $17 \%$ to $8 \%$ and ignorance is constant within the time interval for pre and post KAP study respectively. Finally the respondents (students) are benefitted by KAP study and training sessions. Otherwise percentage of ignorance dramatically has constant for both KAP study activities. Knowledge level of respondents after rabid bite be get death are $53 \%$ and $89.5 \%$, be get a rabid $26 \%$ and $6 \%$, be get a mad $20.5 \%$ and $4 \%$, ignorance 0.5 and same respectively. Awareness level of respondent about death of rabid patient is denoted by yes and/or no $64.5 \%$ and $85 \%$ and /or $35.5 \%$ and $15 \%$ for pre\& post KAP study respectively. So the respondent's awareness increased $20.5 \%$ by the life skill training project on rabies. Knowledge level of respondent about nursing after rabbit bite is wash by hygiene soap or save loan $26 \%$ and $69 \%$, treatment by a doctor $68.5 \%$ and $28 \%$, taking vaccine $4 \%$ and $3 \%$, also ignore $1 \%$ and less by pre to post KAP study respectively. Awareness level of respondents about afraid of dog is yes $63.5 \%$ and $61.5 \%$ and /or No $36.5 \%$ and $38.5 \%$ for rabbit by pre \& post KAP study. The minor percentage of population like $19.5 \%$ and $22.5 \%$ have has 1 to 3 pet dogs domestically for pre and post KAP study respectively. In pre-KAP study $22(11.0 \%)$ students gave the positive responses regarding the presence of puppies in their house and the rest $178(89.0 \%)$ students replied negative. In post-KAP study $18(9.0 \%)$ students gave the positive response and the rest 182(91.0\%) students gave negative response. Sleeping dog was dangerous and these dogs usually more aggressive. In this context 273(68.25\%) students were positive response. Feeding dog was dangerous and these dogs usually more aggressive. In this context 396(99.0\%) students were negative response. Feeding dog was dangerous and these dogs usually more aggressive. In this context $280(70.0 \%)$ students were positive response. Disturbance to eating dogs was dangerous and these dogs usually more aggressive to bit. In this context 397(99.27\%) students were negative response. Eating dogs usually were more aggressive to bit. In this context $286(71.5 \%)$ students were positive response. Majority were responded that they were still stand up in 178(44.5\%) students. Avoidance of the dog was reported by 200(50.0\%) students. Awareness level of students about the Govt. vaccination was evaluated and was found that $345(86.25 \%)$ students knew about it and the rest $55(13.75 \%)$ students unaware of it. In conclusion the school going children is very poor knowledge about the rabies virus regarding the transmission, clinical features and other related issues which is improved after post-KAP study (Figure 1-5).

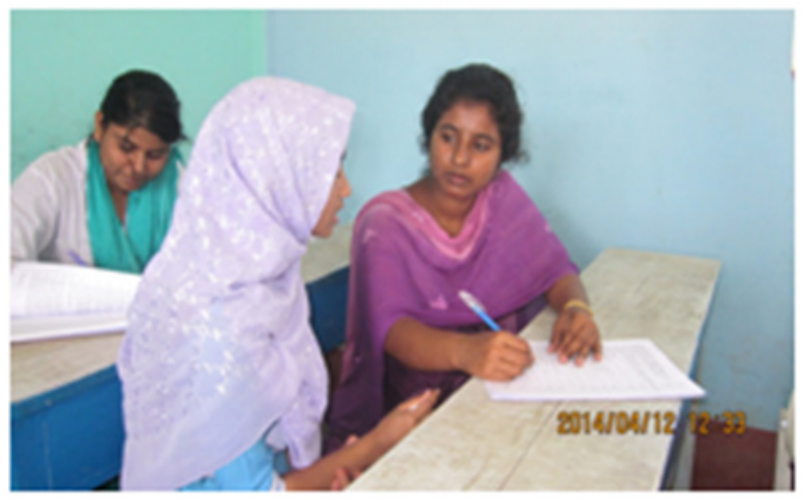

Figure I Data collection from the students in pre KAP study.

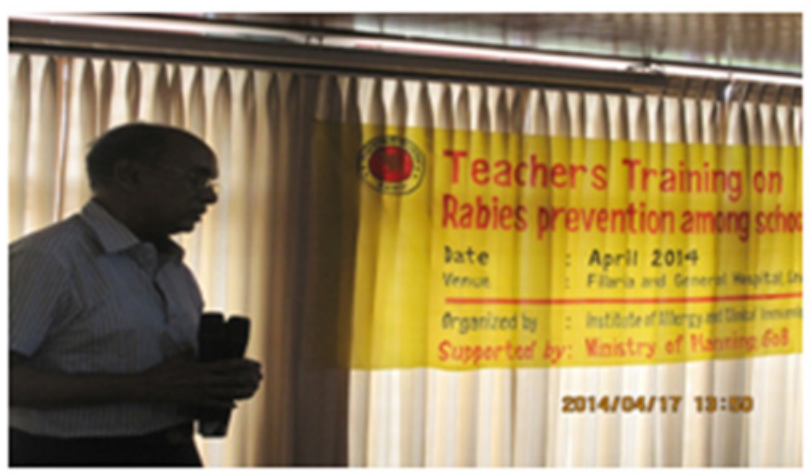

Figure 2 Training session for school teachers by Prof. Dr. Moazzem Hosain before KAP study.

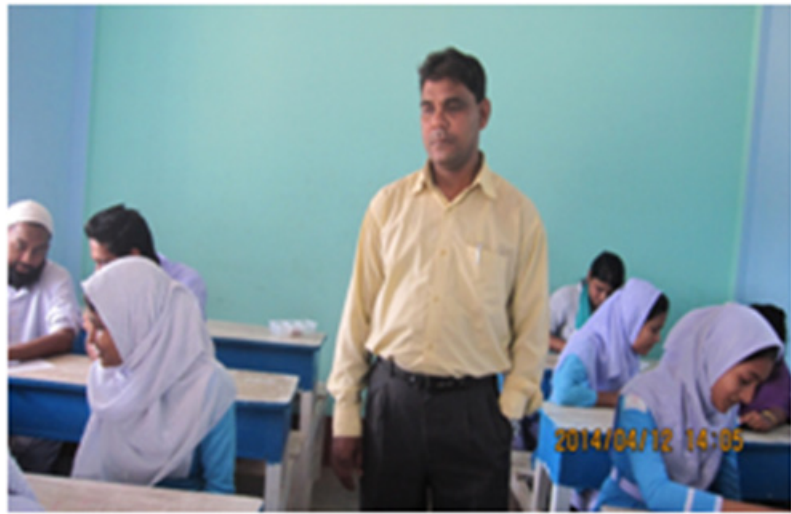

Figure 3 Project co-coordinator is supervising the data collection. 


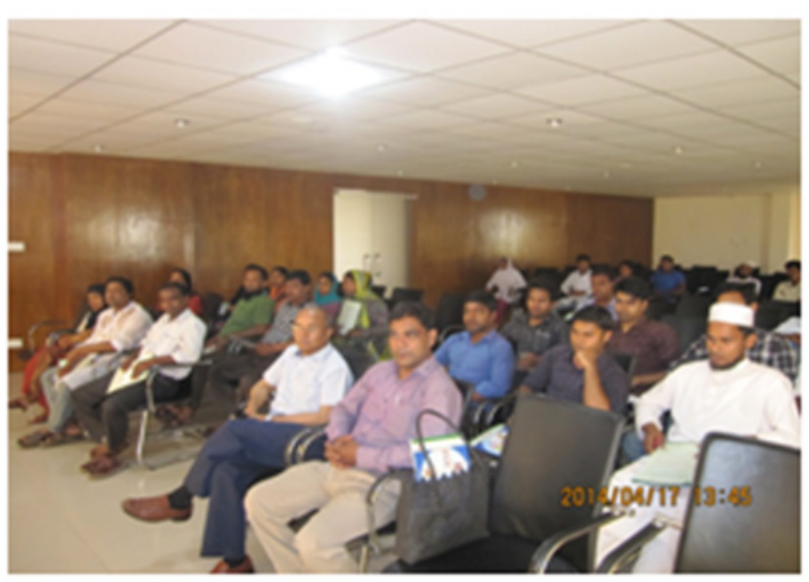

Figure 4 Training sessions for teacher's comments on rabies.

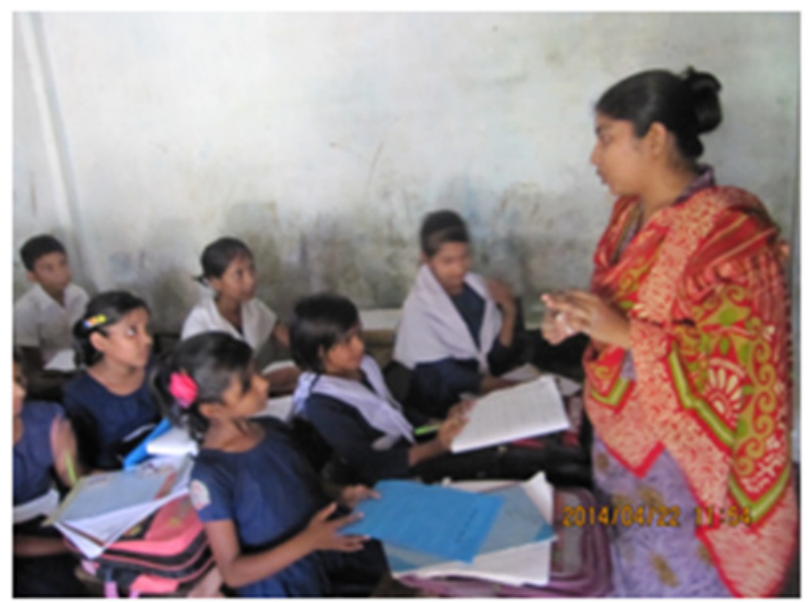

Figure 5 Briefing on rabies prevention among school children by class teacher.

\section{Acknowledgments}

None.

\section{Conflicts of interest}

None.

\section{Funding}

None.

\section{References}

1. Compendium of Animal Rabies Prevention and Control, 2016. JAVMA. 2011;60(6):1-13.

2. Kilic B, Unal B, Semin S, et al. important public health problem: rabies suspected bites and post-exposure prophylaxis in a health district in Turkey. Int J Infect Dis. 2006;10(3):248-254.

3. Ivan VK, Brooke B, Sarah AG, et al. Bats, emerging infectious diseases, and the rabies paradigm revisited. Emerg Health Threats J. 2011;4:10

4. Dimaano EM, Scholand SJ, Alera MT, et al. Clinical and epidemiological features of human rabies cases in the Philippines: a review from 1987 to 2006. Int J Infect Dis. 2011;15(7):495-499.

5. Susilawathi NM, Darwinata AE, Dwija IB, et al. Epidemiological and clinical features of human rabies cases in Bali 2008-2010. BMC Infect Dis. 2012;12:81

6. NaseemSalauddin. Guidelines for Human Rabies Prevention in Pakistan. 2009.

7. Your Right To Know: Human and Animal Rabies Control. Star Health. 2009.

8. Hossain M, Ahmed K, Bulbul T, et al. Human rabies in rural Bangladesh. Epidemiol Infect. 2012; 140(11):1964-1971.

9. Mahardika GNK, Dibia N, Budayanti NS, et al. Phylogenetic analysis and victim contact tracing of rabies virus from humans and dogs in Bali, Indonesia. Infect. 2014;142(6):1146-1154.

10. RozarioMenezes MD. Canadian Medical Association: Rabies in India. CMAJ. 2008;178(5):564-566.

11. Kureishi A, Xu LZ, Wu H, et al. Rabies in China: recommendations for control. Bull World Health Organ. 1992;70(4):443-450. 